\title{
COVID-19 Pandemic, Oil Price Slump and Food Crisis Nexus: An Application of ARDL Approach
}

\author{
Kabiru Saidu Musa ${ }^{*}{ }^{\oplus}$, Rabiu Maijama'a1,2, Nafisa Mohammed ${ }^{1,3}$, Muktari Yakubu ${ }^{1,4}$ \\ ${ }^{1}$ Department of Economics, Faculty of Social and Management Sciences, Bauchi State University Gadau, Yuli Campus, Bauchi, \\ Nigeria \\ ${ }^{2}$ Nigeria National Petroleum Corporation, NNPC Towers, Central Business District, Garki, Abuja, Nigeria \\ ${ }^{3}$ Central Bank of Nigeria, Gombe Branch, Gombe State, Gombe, Nigeria \\ ${ }^{4}$ Ministry of Education, Bauchi, Nigeria \\ Email: ^kabirusaidumusa@gmail.com
}

How to cite this paper: Musa, K.S., Maijama'a, R., Mohammed, N. and Yakubu, M. (2020) COVID-19 Pandemic, Oil Price Slump and Food Crisis Nexus: An Application of ARDL Approach. Open Access Library Journal, 7: e6403.

https://doi.org/10.4236/oalib.1106403

Received: May 8, 2020

Accepted: June 6, 2020

Published: June 9, 2020

Copyright (C) 2020 by author(s) and Open Access Library Inc.

This work is licensed under the Creative Commons Attribution International License (CC BY 4.0).

http://creativecommons.org/licenses/by/4.0/

(c) (i) Open Access

\begin{abstract}
The study investigates the impacts of COVID-19 pandemic on crude oil price and global food price index using an autoregressive distributed lag (ARDL) model and vector error correction (VECM) model covering the sample period of $20^{\text {th }}$ January to $31^{\text {st }}$ March 2020. The result from ARDL model indicates strong cointegration relationship among the variables and that crude oil price is negatively and significantly related to COVID-19 pandemic while food price index appeared to be positive and insignificant in the long run period. But in the short run period both crude oil prices and food price index have negative and significant relationship with COVID-19 pandemic. The VECM Granger causality test result revealed that there is long run causality in COVID-19 pandemic equation and that there is also short run unidirectional causality running from crude oil price to COVID-19 pandemic and from food price index to crude oil price. Therefore, it is concluded that the effect of COVID-19 pandemic on crude oil price and food price index is a short run effect and it is recommended that short run workable measures should be applied by OPEC and FAO in order to rescue crude oil price slump and avoid food crisis.
\end{abstract}

\section{Subject Areas}

Socioeconomics, Sociology

\section{Keywords}

COVID-19 Pandemic, Oil Price Slump, Food Crisis, ARDL Approach and VECM Granger Causality 


\section{Introduction}

On $31^{\text {st }}$ December 2019, the WHO China Country Office was informed of cases of pneumonia unknown etiology (unknown cause) detected in Wuhan City, Hubei Province of China. From $31^{\text {st }}$ December 2019 through $3^{\text {rd }}$ January 2020, a total of 44 case patients with pneumonia of unknown etiology were reported to WHO by the national authorities in China. During this reported period, the causal agent was not identified. The Chinese authorities identified a new type of coronavirus, which was isolated on $7^{\text {th }}$ January 2020. On $11^{\text {th }}$ and $12^{\text {th }}$ January 2020, WHO received further detailed information from the National Health Commission China that the outbreak is associated with exposures in one seafood market in Wuhan city and China shared the genetic sequence of the novel coronavirus for countries to use in developing specific diagnostic kits. On $13^{\text {th }}$ January 2020, the Ministry of Public Health, Thailand reported the first imported case of laboratory confirmed novel coronavirus (2019-nCoV) from Wuhan, Hubei Province, China. On $15^{\text {th }}$ January 2020, the Ministry of Health, Labour and Welfare, Japan (MHLW) reported an imported case of laboratory confirmed 2019-novel coronavirus (2019-nCoV) from Wuhan, Hubei Province, China. On $20^{\text {th }}$ January 2020, National IHR Focal Point (NFP) for the Republic of Korea reported the first case of novel coronavirus in the Republic of Korea [1]. But on 31 January 2020, a total of 9826 confirmed cases of 2019-nCoV have been reported globally with 9720 infected reported cases from China, 15,238 suspected cases, 1527 severe illness and 213 deaths and 106 confirmed cases have been reported outside of China in 19 countries [2].

On 1st February 2020, a total of 11,953 (2128 new) confirmed infected cases of 2019-nCoV have been reported globally with 11,821 (2102 new) confirmed reported cases from China, 1795 (268 new) severe illness and 259 (46 new) deaths. 132 (26 new) confirmed infected cases have been reported outside China in 23 (4 new) countries and out of 132 infected identified cases outside China, 14 were due to secondary transmission from outside China and travel history is available for 101 infected cases [3]. But on the $29^{\text {th }}$ February 2020, the reports revealed that there are 85,403 (1753 new) confirmed infected cases globally and 79,394 (435 new) confirmed infected cases with 2838 deaths (47 new) from China. Reports from outside China indicate that 6009 (1318 new) confirmed infected cases from 53 countries with 86 deaths (19 new) [4].

On $1^{\text {st }}$ March 2020, the total confirmed infected cases of the virus have reached 87,137 (1739 new) globally, 79,968 (579 new) confirmed cases and 2873 (35 new) deaths from china. 7169 (1160 new) confirmed cases with 104 deaths from outside china [5]. But on $31^{\text {st }}$ March 2020, the total confirmed infected cases of the disease have increased to 750,890 (57,610 new) with 36,405 (3301 new) deaths globally. In the western pacific region it was 104,868 (1093 new) confirmed cases with deaths rate of 3671 (22 new), in the European region it was 423,946 (31,131 new) confirmed cases and 26,694 (2733) deaths. In the South East Asia region it was 4215 (131 new) confirmed cases and 166 (8 new) deaths. 
But in the Mediterranean region the figure has reached 50,349 (4020 new) confirmed cases with 2954 (142 new) deaths. In the region of the Americas, the figure of the confirmed case has reached 163,014 (20,935 new) with deaths figure of about 2836 (379 new) and in the African region it was 3786 (300 new) confirmed cases with 77 (17) deaths [6].

On $1^{\text {st }}$ April 2020, the total confirmed cases of the disease has reached 823,626 (72,736 new) with 40,598 (4193 new) deaths globally. In the western pacific region it was 106,422 (1554 new) confirmed cases with deaths rate of 3701 (30 new), in the European region it was 464,212 (40,266 new) confirmed cases and 30,089 (3395 new) deaths. In the South East Asia region it was 5175 (960 new) confirmed cases and 195 (29 new) deaths. But in the Eastern Mediterranean region the figure has reached 54,281 (3932 new) confirmed cases with 3115 (161 new) deaths. In the region of the Americas, the figure of the confirmed case has reached 188,715 (25,737 new) with deaths figure of about 3400 (564 new) and in the African region it has reached 4073 (287 new) confirmed cases with 91 (14 new) deaths [7]. But on the last day of the month, the total confirmed case of the disease has increased to 3,090,445 (71,839 new) with 2177, 69 (9797 new) deaths globally. In the western pacific region it was 147,743 (1294 new) confirmed cases with deaths rate of 6094 (57 new), in the European region it was 1,434,649 $(27,824$ new) confirmed cases and 135,961 (6650 new) deaths. In the South East Asia region it was 54,021 (2670 new) confirmed cases and 2088 (87 new) deaths. But in the Eastern Mediterranean Region the figure has reached 182,417 (5489 new) confirmed cases with 7447 (143 new) deaths. In the region of the Americas, the figure of the confirmed cases has reached 1,246,190 (33,102 new) with deaths figure of about 65,228 (2824 new) and in the African region it has reached 24,713 (1460 new) confirmed cases with 938 (36 new) deaths [8].

\section{Trend of total global infected cases of COVID-19 pandemic}

The total infected cases of COVID-19 pandemic have been rising globally on a daily basis due to human to human transmission of the virus for the past three months as indicates by Figure 1. Figure 1 revealed that there been a continuous upward trend in the total infected cases of COVID-19 pandemic since from $20^{\text {th }}$ January, 2020 up to $31^{\text {st }}$ March, 2020 as shown by the graph below and this necessitate the prevention measures taking by different countries around the globe to prevent the spreads of the disease.

According to IEA, global oil demand is expected to fall in 2020 as the impact of the new coronavirus (COVID-19) spreads around the world, constricting travel and broader economic activity and the demand will decline by a record of 9.3 million barrels per day year on year. The impact of control measures in 187 nations and regions has been to bring mobility nearly to a stop. Demand in the month of April is estimated to be 29 million barrels per day lower than that of 2019, down to a level since last seen in 1995. For the second quarter of 2020 , demand is expected to be 23.1 million barrels per day below 2019 levels. The recovery in $2 \mathrm{H} 20$ will be gradual; in December demand will still be down 2.7 million 
CVC

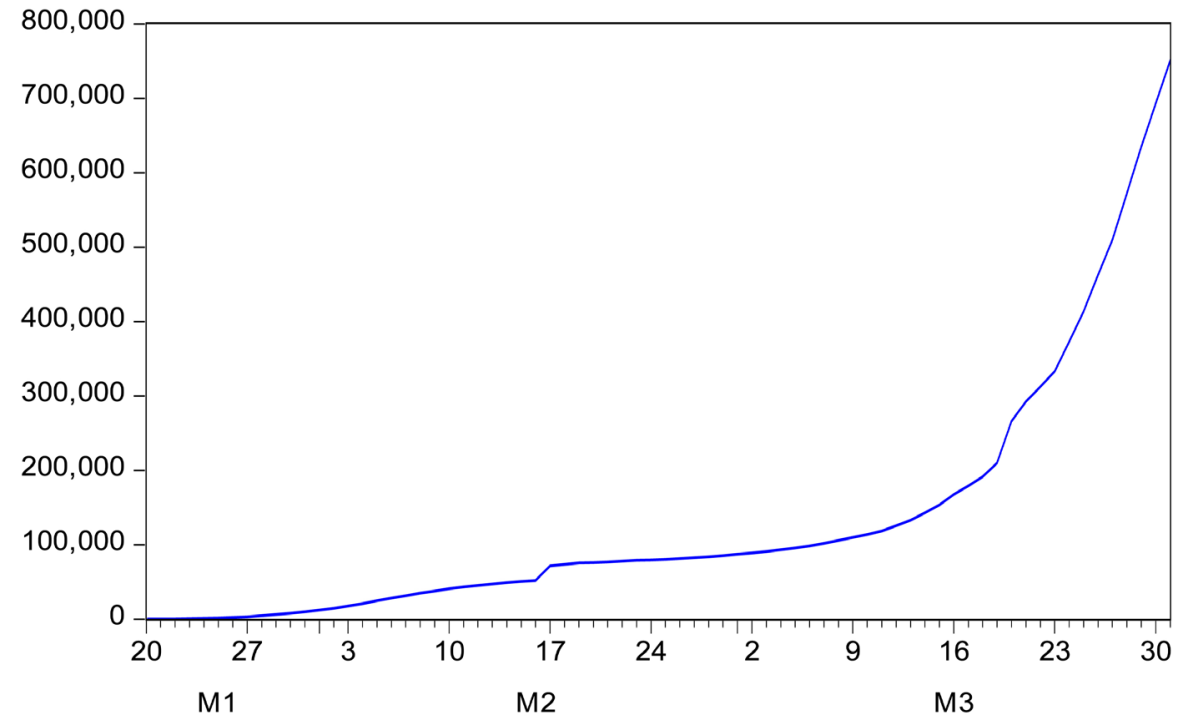

Source: Author's calculation based on data from WHO situation reports.

Figure 1. Global trend of infected cases of COVID-19 pandemic from 1/20/2020 to $3 / 31 / 2020$.

barrels per day year to year [9].

Global oil supply is set to fall by a record of 12 million barrels per day in May 2020, following OPEC plus forged a historic output deal to reduce production by 9.7 million barrels per day from an approved baseline point. An increase in April production will lead to an effective cut of 10.7 million barrels per day. Additional cuts are set to come from additional countries with the US and Canada seeing the biggest cuts. Total non OPEC production falls could attain 5.2 million barrels per day in fourth quarter of 2020, and for the entire year the total output may be 2.3 million barrels per day below that of 2019 [9].

Refining throughout in 2020 is forecast to decrease 7.6 million barrels per day year on year to 74.3 million barrels per day on sharply reduced demand for fuels. Global refinery ingestion is projected to drop by 16 million barrels per day year on year in second quarter of 2020, with extensive shutdowns in all regions and run cuts. Although refinery runs are declining, product stocks are still likely to put up by 6 million barrels per day. In 2H20, refining activity will gradually recover as the international market shifts into shortage [9].

Trend of crude oil price in the international market due to COVID-19 pandemic

The price of Crude oil in the international market has been undergoing fluctuations and fall in prices for the past three months as a result of increase in the infected cases of COVID-19 pandemic. Figure 2 indicates that there has been a continuous downward trend in crude oil price since $20^{\text {th }}$ January, 2020 up to $31^{\text {st }}$ March, 2020 and this call for the short term measure by the OPEC in order to rescue the price.

Currently, some 820 million people around the world are experiencing chronic 


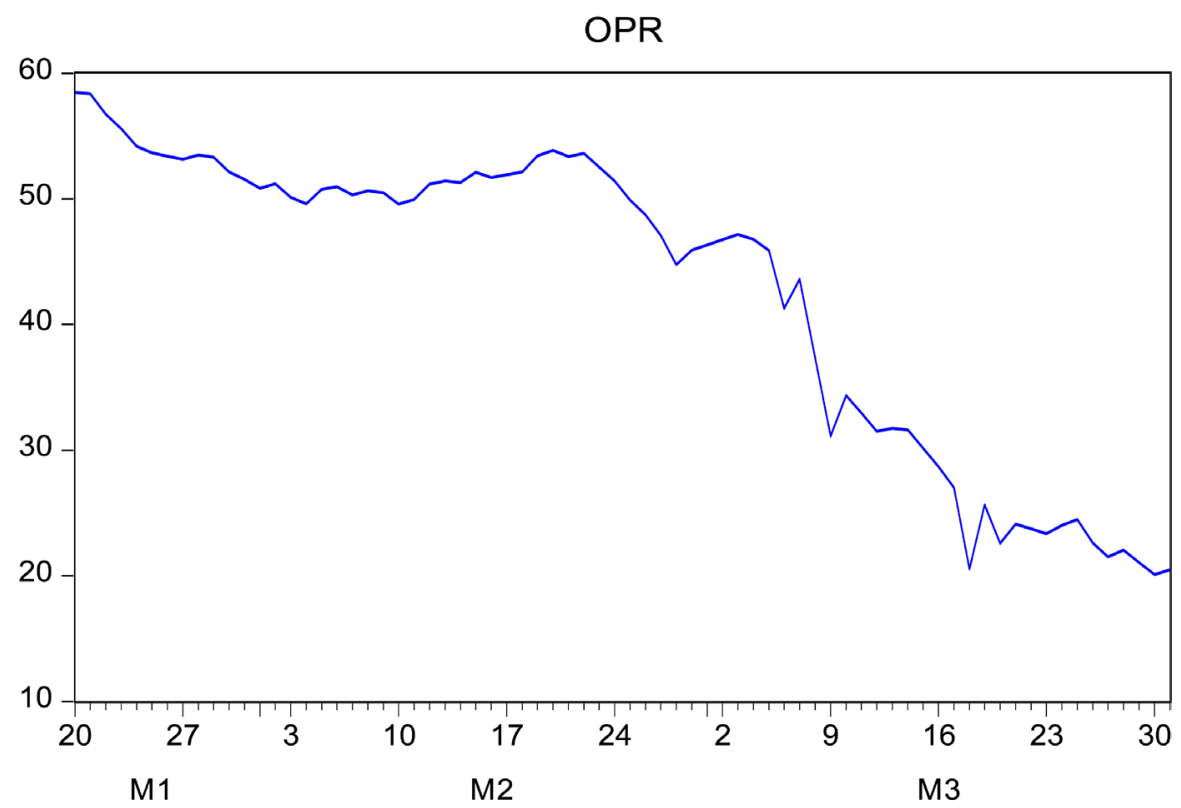

Source: Author's calculation based on data from macrotrend website.

Figure 2. The trend in crude oil price in the international market from $1 / 20 / 2020$ to $3 / 31 / 2020$.

hunger and not eating enough caloric energy to live normal lives. Of these, 113 million are coping with acute severe insecurity and hunger so severe that it poses an immediate threat to their lives or livelihoods and renders them reliant on external assistance to survive. These people can ill afford any potential further disruptions to their livelihoods or access to food that COVID-19 might bring [10].

If COVID-19 cases, already present in most world regions, proliferate in the 44 countries that need external food assistance or in the 53 countries home to 113 million people experiencing acute severe food insecurity, many of whose public health and social protection systems face capacity constraints and the consequences could be drastic [10].

Vulnerable groups also include small scale farmers, pastoralists and fishers who might be hindered from working their land, caring for their livestock, or fishing. They will also face challenges accessing markets to sell their products or buy essential inputs, or struggle due to higher food prices and limited purchasing power. Informal labourers will be hard hit by job and income losses in harvesting and processing. Millions of children are already missing out on the school meals they have come to rely upon, many of them with no formal access to social protection, including health insurance. For example, in Latin America and the Caribbean, FAO supported school meals programmes benefit 85 million children. Some 10 million children depend on them as the meals constitute one of their most reliable sources of food each day. The suspension of the school meals programs due to the pandemic puts vulnerable children's food security and nutrition at risk whilst weakening their capacity to cope with diseases [11].

Food demand is generally inelastic and its effect on overall consumption will 
be likely limited, although dietary patterns may alter. There is a possibility of a disproportionately larger decline in animal protein consumption (as a result of fears and not science based that animals might be hosts of the virus, and other higher valued products like fish, fruits and vegetables (which are likely to cause price slumps). These fears can be particularly true for raw fish products supplied to restaurants and hotels, including small and medium enterprises [12].

Trend of global food price index in the presence of COVID-19 pandemic

The trend in world food price index has also witness downwards sloping trend and fall in food price index from January to March as a result of increasing infected cases of COVID-19 pandemic. Figure 3 indicates that there been a continuous downward trend in food price index from $20^{\text {th }}$ January, 2020 up to $31^{\text {st }}$ March, 2020 and this call for the workable strategies and measures by FAO in order to avoid global food crisis.

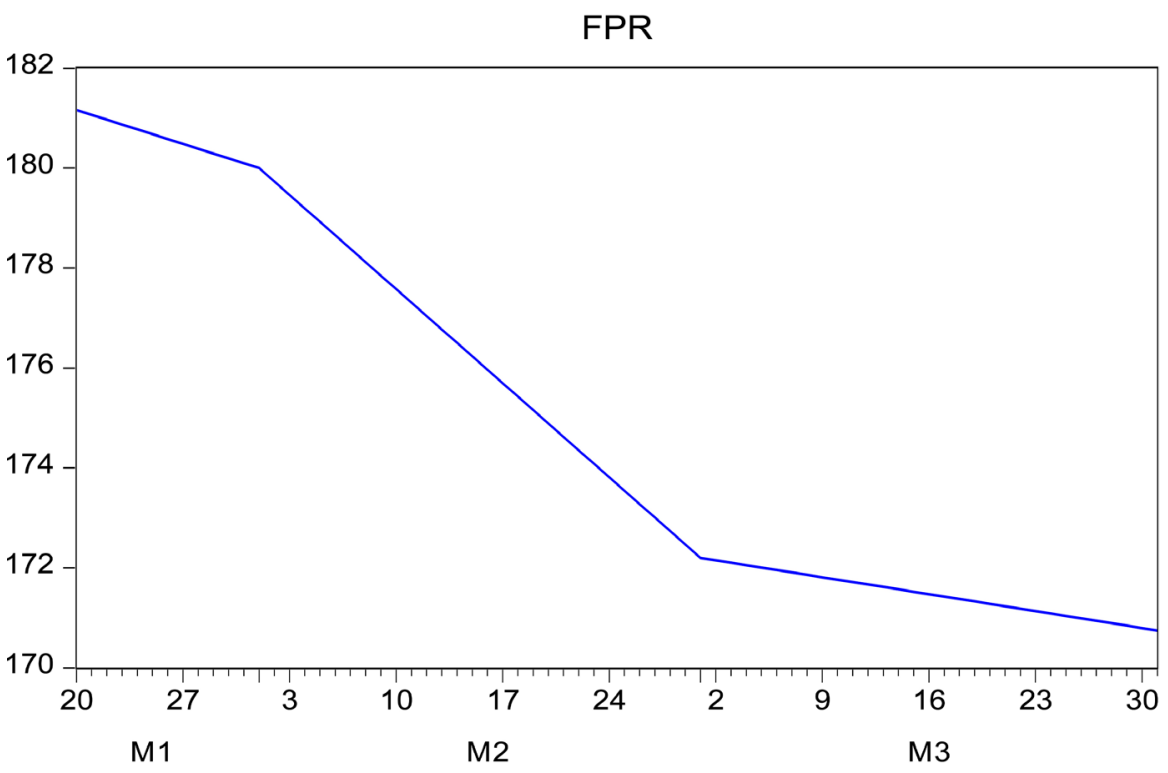

Source: Author's calculation based on data from FAO website.

Figure 3. The trend in global daily food price index from 1/20/2020 to 3/31/2020.

\section{Data and Model Specification}

The study involves three variables namely coronavirus cases, food prices index and oil price. Given that the research paper is trying to investigate the impact of coronavirus pandemic on global oil price and food prices for the period under study, we have restricted the amount of variables to coronavirus infected cases, global crude oil price and global food price index if not adding any variable may change the outcome of the analysis.

The study will adopt and modify the model of [13] who studied the impact of coronavirus outbreak on global energy demand: a case of the People's Republic of China. The model can be finally written as:

$$
C V C=F(O P R, F P R)
$$


The econometric form of the model will take the following form in Equation (2).

$$
C V C_{t}=\beta_{0}+\beta_{1} O P R_{t}+\beta_{2} F P R_{t}+\varepsilon_{t}
$$

where:

$C V C_{t}=$ Coronavirus infected cases, $O P R_{t}=$ Global Oil price, $F P R_{t}=$ Global Food price index, $\beta_{1}-\beta_{2}$ are the coefficients of explanatory variables, $t$ is the time trend and $\varepsilon_{t}$ is the error term.

Note: The data on all on total infected cases of COVID-19 pandemic, global crude oil price and global food price index were sourced from [14] [15] and [16] in form of monthly observations and were disaggregated to daily obsevartions using Eviews 9 which produced a total of 72 days observations.

Introducing natural logarithmic function in the model will help to improve the assumption of linearity, eliminates the problems of multicollinearity, heteroscedasticity and provides easy way of interpreting the coefficients in terms of elasticity [17]. Therefore, the model equation written in natural logarithmic form is given in Equation (3).

$$
\ln C M C_{t}=\beta_{0}+\beta_{1} \ln O P R_{t}+\beta_{2} \ln F P R_{t}+\varepsilon_{t}
$$

where: $\ln$ is the natural $\log \operatorname{sign}, \ln C M C_{t}$ is the natural $\log$ of coronavirus infected cases; $\ln O P R_{t}$ is the natural log of global crude oil price; $\ln F P R_{t}$ is the natural $\log$ of global food price index, $t$ is the time trend and $\varepsilon_{t}$ is the error term.

ARDL model

$$
\begin{aligned}
\Delta C M C_{t}= & \beta_{0}+\sum_{i=1}^{k} \chi_{1 i} \Delta \ln C V C_{t-i}+\sum_{i=0}^{k} \delta_{1 i} \Delta \ln O P R_{t-i}+\sum_{i=0}^{k} \phi_{1 i} \Delta \ln F P R_{t-i} \\
& +\alpha_{1 i} \ln C V C_{t-i}+\alpha_{2 i} \ln O P R_{t-i}+\alpha_{3 i} \ln F P R_{t-i}+\varepsilon_{1 t}
\end{aligned}
$$

where: $C V C_{t}=$ Coronavirus infected cases, $O P R_{t}=$ Global oil price, $F P R_{t}=$ Global Food price index, $\chi, \delta$ and $\phi$ are the short run coefficients, $\Delta$ is the short run parameter, $\alpha_{1}-\alpha_{2}$ are the long run coefficients, $k$ is the maximum lag, $t$ is the time trend and $\varepsilon_{t}$ is the error term.

Subsequent to the ARDL model supplied in the Equation (4) above for the impact of COVID-19 pandemic on crude oil price and food prices, the ADRL model is divided into four sub models. The first model is the bound test model, the second model is the long run model, the third model is the short run model and the fourth model is the short run and error correction model respectively.

\section{ARDL bound test model}

To test for the existence of cointegration relationship among COVID-19 pandemic, crude oil price and food prices the model Equation (5) is specified and estimated using ARDL bound test. The model contained the null and alternative hypotheses which may be accepted or rejected and this stand a decision point when the null hypothesis of no long run relationship between variables is accepted as against the alternative hypothesis of long run relationship, and then some methods which include VECM among others can be amply applied. If on the other hand there is an existence of long run relationship resulting from the 
rejection of the null hypothesis, then long run and short run coefficients can be calculated. Therefore, the specified model for long run relationship is given in the equation below:

$$
\begin{aligned}
\Delta \ln C V C_{t}= & \beta_{1}+\sum_{i=1}^{k} \chi_{2 i} \Delta \ln C V C_{t-i}+\sum_{i=0}^{k} \delta_{2 i} \Delta \ln O P R_{t-i}+\sum_{i=0}^{k} \phi_{2 i} \Delta \ln F P R_{t-i} \\
& +\alpha_{1} \ln C V C_{t-i}+\alpha_{2} \ln O P R_{t-i}+\alpha_{3} \ln F P R_{t-i}+\varepsilon_{2 t}
\end{aligned}
$$

where: $C V C_{t}=$ Coronavirus infected cases, $O P R_{t}=$ Global crude oil price, $F P R_{t}=$ Global food price index, $\chi, \delta$ and $\phi$ are the short run coefficients, $\Delta$ is the short run parameter, $\alpha_{1}-\alpha_{2}$ are the long run coefficients, $k$ is the maximum lag, $t$ is the time trend and $\varepsilon_{2 t}$ is the error term.

The null and alternate hypotheses of the cointegration model are stated in the equation below. When $\mathrm{H}_{0}$ is accepted then there is no cointegration but when $\mathrm{H}_{0}$ is rejected and $\mathrm{H}_{1}$ is accepted then cointegration relationship exists among the variables.

$$
\begin{aligned}
& \mathrm{H}_{0}: \alpha_{1}=\alpha_{2}=\alpha_{3}=0 \text { ( No Cointegration) } \\
& \mathrm{H}_{1}: \alpha_{1} \neq \alpha_{2} \neq \alpha_{3} \neq 0 \text { (Cointegration Exist) }
\end{aligned}
$$

\section{ARDL long run model}

Due to the existence of cointegration relationship among the variables in the cointegration model, then the estimation of the long run coefficients becomes compulsory. To get the estimated long run coefficients, Equation (6) below is correctly specified and estimated to obtain the long run coefficients.

$$
\ln C V C_{t}=\beta_{3}+\sum_{i=1}^{k} \alpha_{1 i} \ln C V C_{t-i}+\sum_{i=0}^{k} \alpha_{2 i} \ln O P R_{t-i}+\sum_{i=0}^{k} \alpha_{3 i} \ln F P R_{t-i}+\varepsilon_{3 t}
$$

where: $C V C_{t}=$ Coronavirus infected cases, $O P R_{t}=$ Global crude oil price, $F P R_{t}=$ Global food price index, $\alpha_{1}-\alpha_{2}$ are the long run coefficients, $k$ is the maximum lag, $t$ is the time trend and $\varepsilon_{2 t}$ is the stochastic error term.

\section{ARDL short run model}

Due to the existence of the long run relationship and the coefficients of long run model in equation 6 above, the estimation of the short run coefficients become necessary and the Equation (7) is properly specified and estimated in order to obtain these short run coefficients of the variables.

$$
\begin{aligned}
\Delta \ln C V C_{t}= & \beta_{4}+\sum_{i=1}^{k} \chi_{3 i} \Delta \ln C V C_{t-i}+\sum_{i=0}^{k} \delta_{3 i} \Delta \ln O P R_{t-i} \\
& +\sum_{i=0}^{k} \phi_{3 i} \Delta \ln F P R_{t-i}+\varepsilon_{4 t}
\end{aligned}
$$

where: $C V C_{t}=$ Coronavirus infected cases, $O P R_{t}=$ Global crude oil price, $F P R_{t}=$ Global food price index, $\chi, \delta$ and $\phi$ are the short run coefficients, $\Delta$ is the short run parameter, $k$ is the maximum lag, $t$ is the time trend and $\varepsilon_{4 t}$ is the error term.

\section{ARDL short-run and error correction model}

To get the short run coefficients and the coefficient of error correction term 
that measure the speed of adjustment or convergence back to the equilibrium position from the position of disequilibrium, the Equation (8) is also properly specified and estimated to get this value

$$
\begin{aligned}
\Delta \ln C V C_{t}= & \beta_{5}+\sum_{i=1}^{k} \chi_{4 i} \Delta \ln C V C_{t-i}+\sum_{i=0}^{k} \delta_{4 i} \Delta \ln O P R_{t-i} \\
& +\sum_{i=0}^{k} \phi_{4 i} \Delta \ln F P R_{t-i}+\vartheta E C T_{t-1}+\varepsilon_{5 t}
\end{aligned}
$$

where: $C V C_{t}=$ Coronavirus infected cases, $O P R_{t}=$ Global oil price, $F P R_{t}=$ Global food price index, $\chi, \delta$ and $\phi$ are the short run coefficients, $\Delta$ is the short run parameter, $\vartheta$ is the coefficient of error term, $k$ is the maximum lag, $t$ is the time trend and $\varepsilon_{5 t}$ is the error term.

\section{VECM Granger causality}

The determination of the direction of causality between COVID-19 pandemic, crude oil prices and food price index is done by VECM granger causality in order to determine the short run dynamic relationship between these variables. According to [18] most variables that are optimally forecasted from their own lagged values would have all their forecast error variances accounted for by their own disturbances.

Again, the VECM Granger causality is considered paramount for testing causality between variables of the same level of stationarity or order of integration, that is, when all the variables are stationary at first difference or I(1) and cointegrated. The vector error correction model (VECM) has some advantages over the granger causality test such as ability to provide short run and long run causalities and it is also base on system of equations. The vector error correction model (VECM) modeling equation contained by a system of error correction model (ECM) for this study is given in a matrix form below:

$$
\begin{aligned}
& {\left[\begin{array}{c}
\Delta \ln C V C_{t} \\
\Delta \ln O P R_{t} \\
\Delta \ln F P R_{t}
\end{array}\right]=\left[\begin{array}{l}
\chi_{0} \\
\delta_{0} \\
\phi_{0}
\end{array}\right]+\sum_{i=1}^{k}\left[\begin{array}{lll}
\chi_{1 i} & \chi_{2 i} & \chi_{3 i} \\
\delta_{1 i} & \delta_{2 i} & \delta_{3 i} \\
\phi_{1 i} & \phi_{2 i} & \phi_{3 i}
\end{array}\right] \times\left[\begin{array}{c}
\Delta \ln C V C_{t-1} \\
\Delta \ln O P R_{t-1} \\
\Delta \ln F P R_{t-1}
\end{array}\right]+\left[\begin{array}{l}
\vartheta_{1} \\
\vartheta_{2} \\
\vartheta_{3}
\end{array}\right]\left(E C T_{t-1}\right)+\left[\begin{array}{l}
\mu_{1 t} \\
\mu_{2 t} \\
\mu_{3 t}
\end{array}\right] } \\
& \Delta \ln C V C_{t}= \chi_{0}+\sum_{i=1}^{k} \chi_{1 i} \Delta \ln C V C_{t-1}+\sum_{i=1}^{k} \chi_{2 i} \Delta \ln O P R_{t-1} \\
&+\sum_{i=1}^{k} \chi_{3 i} \Delta \ln F P R_{t-1}+\vartheta_{1} E C T_{t-1}+\mu_{1 t} \\
& \Delta \ln O P R_{t}= \delta_{0}+\sum_{i=1}^{k} \delta_{1 i} \Delta \ln C V C_{t-1}+\sum_{i=1}^{k} \delta_{2 i} \Delta \ln O P R_{t-1} \\
&+\sum_{i=1}^{k} \delta_{3 i} \Delta \ln F P R_{t-1}+\vartheta_{2} E C T_{t-1}+\mu_{2 t} \\
& \Delta \ln F P R_{t}= \phi_{0}+\sum_{i=1}^{k} \phi_{1 i} \Delta \ln C V C_{t-1}+\sum_{i=1}^{k} \phi_{2 i} \Delta \ln O P R_{t-1} \\
&+\sum_{i=1}^{k} \phi_{3 i} \Delta \ln F P R_{t-1}+\vartheta_{3} E C T_{t-1}+\mu_{3 t}
\end{aligned}
$$

where the error correction term's coefficients are represented by $\vartheta_{1}-\vartheta_{3}$, the 
homoscedastic disturbance terms are denoted by $\mu_{1}-\mu_{3}$, the error correction term is denoted by $E C T_{t-1}$. The $E C T_{t-1}$ indicates the long run causality and the speed of adjustment toward long run equilibrium, while the Wald test statistic of the first difference of the variables shows the short run causality and its direction.

\section{Results and Discussions}

This section presents the results of the estimation and the discussions of the findings in relation to the present study. The descriptive statistics are presented in Table 1 with the correlation analysis of the variables presented in Table 2. The descriptive statistics results revealed that the observations are equal meaning there are 72 numbers of observations. The approximated mean values are; CVC (133655.8), OPR (42.71568 USD/barrel), FPR (174.9173 USD). The Jarque-Bera probability values indicate that OPR and FPR are not normally distributed within the study period. The analyses further indicate that $C V C$ and $F P R$ variables are positively skewed while $O P R$ is negatively skewed. The variability returned indicated by the standard deviation statistics showed that $C V C$ $(170,650.0), O P R$ (12.327) and FPR (3.683). Comparatively, these values shows that, two of these variables that include $O P R$ and $F P R$ are clearly dispersed below the mean value and median value while only $C V C$ variable that its standard deviation value is above its mean and median values.

Table 1. Descriptive analysis of the variables.

\begin{tabular}{cccccccccc}
\hline Variables & Obs & Mean & Median & Max. & Min. & Std. Dev. & Skewness & Kurtosis & Prob. \\
\hline CVC & 72 & $133,655.8$ & $79,785.00$ & $750,890.0$ & 282.0000 & $170,650.0$ & 2.052528 & 6.620108 & 0.000 \\
OPR & 72 & 42.71568 & 49.59000 & 58.46800 & 20.09000 & 12.32742 & -0.701279 & 1.877292 & 0.007 \\
FPR & 72 & 174.9173 & 173.6793 & 181.1613 & 170.7484 & 3.683435 & 0.448454 & 1.610623 & 0.016
\end{tabular}

Sources: Authors Computation using EViews 9; Note: Prob. means Jarque-Bera P-Values.

Coming down to correlation analysis reported in Table 2, all the variables are in natural logarithmic form. The result indicates that crude oil price and food price index have negative correlation with the infected cases of COVID-19 pandemic. This means that increase in the infected cases of COVID-19 pandemic will cause a decrease in crude oil prices and food price index for the entire periods under study.

Table 2. Correlation coefficients of monetary variables and food prices.

\begin{tabular}{cccc}
\hline Variables & $\ln C V C$ & $\ln F P R$ & $\ln O P R$ \\
\hline $\ln C V C$ & 1.000 & & \\
$\ln O P R$ & -0.719 & 1.000 & \\
$\ln F P R$ & -0.894 & 0.758 & 1.000 \\
\hline
\end{tabular}

Sources: Author's Computation using EViews 9. 
To inspect the property of the data before estimating the long run equilibrium relationship, the following are required. At first, we check for the stationarity or integration properties of the data by means of breakpoint unit root test given that it has the ability to tackled issue of structural breaks, drift and trend in the series. The result of breakpoint unit root test is reported in Table 3. The breakpoint unit root test result indicates that $C V C$ and $F P R$ are stationary at level value and they are said to be integrated of order I (0) while $O P R$ is stationary at first difference and is said to be integrated of order I (1). In summary, the breakpoint unit root test result indicates the combination of I (1) and I (0) variables. For this reason, the result of breakpoint unit root test supports the application of Autoregressive Distributed Lag (ARDL) model.

Table 3. Breakpoint unit root test result.

\begin{tabular}{cccccccccc}
\hline Level value & \multicolumn{1}{c}{ First difference } \\
\hline Variables & Constant & $\begin{array}{c}\text { Break } \\
\text { Point }\end{array}$ & $\begin{array}{c}\text { Constant } \\
\text { \& trend }\end{array}$ & $\begin{array}{c}\text { Break } \\
\text { point }\end{array}$ & Constant & $\begin{array}{c}\text { Break } \\
\text { point }\end{array}$ & $\begin{array}{c}\text { Constant } \\
\& \text { trend }\end{array}$ & Break point & I (d) \\
\hline $\ln C V C$ & $-8.896(0)^{\mathrm{a}}$ & $3 / 19 / 20$ & $-9.190(2)^{\mathrm{a}}$ & $3 / 27 / 20$ & - & - & - & - & $\mathrm{I}(0)$ \\
$\ln O P R$ & $-3.178(1)$ & $3 / 07 / 20$ & $-5.172(0)^{\mathrm{a}}$ & $3 / 07 / 20$ & $-15.096(0)^{\mathrm{a}}$ & $3 / 18 / 20$ & $-16.084(0)^{\mathrm{a}}$ & $3 / 18 / 20$ & $\mathrm{I}(1)$ \\
$\ln F P R$ & $-2.101(1)$ & $3 / 30 / 20$ & $-6.428(0)^{\mathrm{a}}$ & $3 / 02 / 20$ & $-4.122(0)$ & $3 / 01 / 20$ & $-5.869(0)^{\mathrm{a}}$ & $3 / 01 / 20$ & $\mathrm{I}(0)$ \\
\hline
\end{tabular}

Source: Eviews 9; Note: ${ }^{\text {a }}$ stands for $1 \%$ level of significance and values in brackets are the lag lengths, while I (d) stands for the interpretation of the results.

From the results of the unrestricted vector autoregression (VAR) reported in Table 4, using sequentially modified LR test statistic, Final Prediction Error, Akaike Information Criterion (AIC), Schwarz criterion (SC) and Hannan-Quinn criteria (HQ) each test at $5 \%$ level of significant revealed that lag 2 should be selected. Therefore, in line with these Information Criterions, lag 2 is the maximum lags length for this study.

Table 4. VAR lag order selection criteria.

\begin{tabular}{ccccccc}
\hline Lag & LogL & LR & FPE & AIC & SC & HQ \\
\hline 0 & 116.2937 & NA & $7.17 \mathrm{e}-06$ & -3.332168 & -3.234248 & -3.293369 \\
1 & 660.1101 & 1023.654 & $1.06 \mathrm{e}-12$ & -19.06206 & -18.67038 & -18.90687 \\
2 & 708.6695 & $87.12132^{\mathrm{k}}$ & $3.31 \mathrm{e}-13^{\mathrm{k}}$ & $-20.22557^{\mathrm{k}}$ & $-19.54014^{\mathrm{k}}$ & $-19.95398^{\mathrm{k}}$ \\
3 & 713.7549 & 8.675017 & $3.73 \mathrm{e}-13$ & -20.11044 & -19.13124 & -19.72245 \\
4 & 717.1898 & 5.556477 & $4.43 \mathrm{e}-13$ & -19.94676 & -18.67381 & -19.44238 \\
\hline
\end{tabular}

Sources: Authors computation using EViews 9. Note; k refers to the lag selected by different information criteria's.

Having known the optimum lag length, the next step is to determine the cointegration relationship among the series by employing ARDL bounds test. The null hypothesis of no cointegration $\left(\mathrm{H}_{0}: \alpha_{1}=\alpha_{2}=\alpha_{3}=0\right)$ was tested along with the alternative hypothesis of cointegration relationship $\left(\mathrm{H}_{\mathrm{a}}: \alpha_{1} \neq \alpha_{2} \neq \alpha_{3} \neq 0\right)$. The product of this test depicted in Table 5 revealed that the null hypothesis of 
no cointegration relationship among the series was rejected for the entire period under study (i.e. $1 / 20 / 2020$ to $3 / 31 / 2020$ ), at $1 \%$ level of significance. Because the estimated F-statistics value of 31.469 exceeded the lower bound critical value of 5.15 and the upper bound critical of value of 6.36 at the aforementioned level of significance. As such, existence of cointegration relationship is confirmed in this respect. Meaning the series are moving together or that they split an ordinary association in the long run.

Table 5. Bounds test result for ARDL $(1,0,0)$ using Schwarz criterion (SIC).

\begin{tabular}{cccccc}
\hline & & \multicolumn{4}{c}{ Bound test critical values } \\
& & \multicolumn{5}{c}{ [unrestricted intercept \& no trend] } \\
\hline Model & F-stat. & Lag & Level of significance & I (0) & I (1) \\
\hline $1 / 20 / 2020$ to 3/31/2020 & 31.469 & 2 & $1 \%$ & 5.15 & 6.36 \\
$F\left(\ln C V C_{t} / \ln O P R_{t} \ln F P R_{t}\right)$ & & $5 \%$ & 3.79 & 4.85 \\
$K=2 \& n=72$ & & $10 \%$ & 3.17 & 4.14 \\
\hline
\end{tabular}

Sources: Authors computation using EViews 9.

The Johansen Juselius test for cointegration relationship using representation with Trace statistic and representation with Max-Eigen value statistic as reported in Table 6 revealed the existence of 2 cointegration equations in the trace statistic representation and 2 cointegration equations in the max-eigen statistic representation. Therefore, we bring to a close that there is a cointegration relationship among explaining and the explanatory variables and that all the variables moved jointly in the long run. The Johansen Juselius test for cointegration result corroborates the bounds test result of ARDL.

Table 6. Johansen Juselius test for cointegration.

\begin{tabular}{cccccc}
\hline Hypothesized & Eigenvalue & Trace Statistic & $\mathbf{0 . 0 5}$ & Max-Eigen & $\mathbf{0 . 0 5}$ \\
\hline No. of CE(s) & & & Critical Value & Statistic & Critical Value \\
\hline$C=0$ & 0.713 & $106.990^{\mathrm{a}}(0.000)$ & 29.797 & $86.207^{\mathrm{a}}(0.000)$ & 21.131 \\
$C \leq 1$ & 0.222 & $20.783^{\mathrm{a}}(0.007)$ & 15.494 & $17.380^{\mathrm{a}}(0.015)$ & 14.264 \\
$C \leq 2$ & 0.048 & $3.403(0.065)$ & 3.841 & $3.403(0.065)$ & 3.841 \\
\hline
\end{tabular}

Sources: Authors computation using EViews 9; Note: Values in parentheses are the P-values and a represent statistically significant at $1 \%$ level of significance.

Following the establishment of cointegration relationship among the variables, the long run and short run models in equation 6 and equation 7 were estimated to get these long run and short run coefficients as reported in Table 7 below. The results revealed that food price index is positive and insignificant for the entire study period in the long run.

But crude oil price is negative and significant due to changes in the infected cases of the virus. Specifically, a unit change in crude oil price per barrel is associated with 5.698 percent decrease in the infected cases of the virus in the long run. This 
indicates that increase in the infected cases of COVID-19 will continue to cause decrease in crude oil price in the international market in the long run period.

Table 7. Long run and short run coefficients for ARDL $(1,0,0)$ using Schwarz criterion (SIC).

\begin{tabular}{|c|c|c|c|c|}
\hline \multicolumn{5}{|c|}{ Dependent Variable $=\ln C V C_{t}$} \\
\hline Variable & Coefficient & Std. Error & t-Statistic & Prob. \\
\hline $\ln F P R_{t}$ & 75.427 & 46.803 & 1.611 & 0.111 \\
\hline $\ln O P R_{t}$ & $-5.698^{\mathrm{a}}$ & 1.856 & -3.070 & 0.003 \\
\hline$C$ & -355.030 & 234.641 & -1.513 & 0.135 \\
\hline \multicolumn{5}{|c|}{ Dependent Variable $=\Delta \ln C V C_{t}$} \\
\hline Variable & Coefficient & Std. Error & t-Statistic & Prob. \\
\hline$\Delta \ln F P R_{t}$ & $3.227^{\mathrm{a}}$ & 1.188 & 2.715 & 0.008 \\
\hline$\triangle \ln O P R_{t}$ & $-0.243^{\mathrm{a}}$ & 0.044 & -5.452 & 0.000 \\
\hline$E C M(-1)$ & $-0.042^{\mathrm{a}}$ & 0.012 & -3.475 & 0.000 \\
\hline
\end{tabular}

$e c m=\ln C V C_{t}-75.427 \times \ln F P R_{t}+5.698 \times \ln O P R_{t}+355.030 . \mathrm{R}^{2}: 0.997$, Adjusted R-squared: 0.997, DW-statistic: 1.594, F-stat: $10,540.33^{\mathrm{a}}(0.000)$, Schwarz criterion: -1.950 , Akaike info criterion: -2.077. Sources: Authors computation using EViews 9; Note. AIC = Akaike Information Criterion, ECM = Error Correction Model. a, b \& c and are significant at $1 \%, 5 \%$ \& $10 \%$ levels of significance.

Coming down to the short run outcome also reported in Table 7, the results indicates that food price index appeared to be positive and significant at $1 \%$ level of significance due to infected COVID-19 cases. Meaning that $1 \%$ increase in food price index is associated with $3.227 \%$ increases in infected cases of COVID-19 pandemic in the short run period.

While crude oil price appeared to be negative and significant at $1 \%$ level of significance due to the infected cases of the virus in the short run period. This means that infected cases of the virus shared negative relationship with crude oil prices.

The error correction value of -0.042 satisfied the econometrics requirements of negative value, less than one in value and statistically significant which means that the feedback or convergence rate to long run equilibrium is $4.2 \%$. Precisely, the error correction term value of -0.042 indicates that the long run deviation from the infected cases of COVID-19 pandemic is corrected by $4.2 \%$ every day.

$0.997 \mathrm{R}$-square value implies that $99 \%$ variation in the infected cases of COVID-19 pandemic can be jointly explained by the explanatory variables (i.e., OPR \& FPR) and only $1 \%$ variation in infected cases of COVID-19 pandemic is explained by the error term.

1.594 Durbin Watson (DW) statistic implies that the model is free from first order serial correlation as the value is out of the lower and upper range of 1.50 and 2.50 .

The test for the overall significant of the model depends on the significance of F-statistic and the F-statistic value of $10,540.33$ which is highly significant at $1 \%$ level of significance indicates that all the explanatory variables (OPR \& FPR) in 
the model are jointly significant in explaining the changes in the infected cases of COVID-19 pandemic.

To guarantee the reliability of the estimated coefficients, the reliability tests of serial correlation using Breusch-Godfrey serial correlation LM test, functional form test using Ramsey RESET test, normality test using Jarque-Berra test and the heteroskedasticity using Autoregressive conditional heteroscedasticity (ARCH) test were applied and the outcomes are reported in Table 8. The outcomes showed that the null hypotheses for the serial correlation LM test, functional form and heteroskedasticity test could not be rejected for the model as their probability values were not significant but for normality test the null hypothesis is rejected. This shows that the model is reliable for policy making and statistical inferences.

Table 8. Residuals of the autoregressive distributed lag diagnostic tests.

\begin{tabular}{ccc}
\hline Test statistics & LM version & F-version \\
\hline Serial correlation & CHQ $(2)=0.663[0.518]$ & $\mathrm{F}(2,65)=1.421[0.491]$ \\
Functional form & Not applicable & $\mathrm{F}(1,66)=1.324[0.253]$ \\
Normality & $\mathrm{JB}=166.966^{\mathrm{a}}[0.000]$ & Not applicable \\
Heteroscedascity & $\mathrm{CHQ}(4)=2.854[0.582]$ & $\mathrm{F}(4,62)=0.601[0.239]$ \\
CUSUM & Unstable & \\
CUSUMSQ & Unstable & \\
\hline
\end{tabular}

Sources: Authors computation using EViews 9; Note. Values in [ ] are the probability values. LM = Langrange multiplier test, $\mathrm{CHQ}=$ chi-square .

In determining the stability of the estimated coefficients of infected cases of COVID-19 pandemic equation, the cumulative sum (CUSUM) and cumulative sum of squares (CUSUMSQ) tests as suggested by [19] were utilized.

From Figure 4 and Figure 5 of CUSUM and CUSUMSQ, it can be noticed that both the CUSUM and CUSUMSQ plots pass through the $5 \%$ critical boundaries, indicating that over the entire study period of $1 / 20 / 2020$ to $3 / 31 / 2020$, there is no existence of stability among the estimated coefficients.

As strength checks to the ARDL results, we have employed dynamic OLS, fully modified OLS and Canonical CR, and their coefficients are reported in Table 9. The outcomes revealed that crude oil prices and food price index are negative and significant at $1 \%$ and $10 \%$ levels of significant under DOLS, FMOLS and CCR. Therefore, crude oil price and food price index coefficients corroborate the long run ARDL coefficients as reported in Table 7. The normality test results reported at the lower part of Table 9 indicates that the models under FMOLS and CCR are normally distributed along the study period.

After checking the strength of ARDL long run coefficients, then causal link between the variables was checked using VECM Granger causality test in a vector autoregressive (VAR) system. The existence of long run relationship as represented in Table 5 and Table 6 suggests the existence of causal relation in at 
least one direction. The estimated short run and long run causality results are offered in Table 10 and the summary of causality outcome is given in Table 11. The long run causality results reveal that $E C T_{t-1}$ in infected cases of COVID-19 pandemic equation has fulfilled the econometrics requirements of negative, less than one in value and statistically significant. This suggests that there is a long run causality running from food price index, crude oil price to infected cases of COVID-19 pandemic.

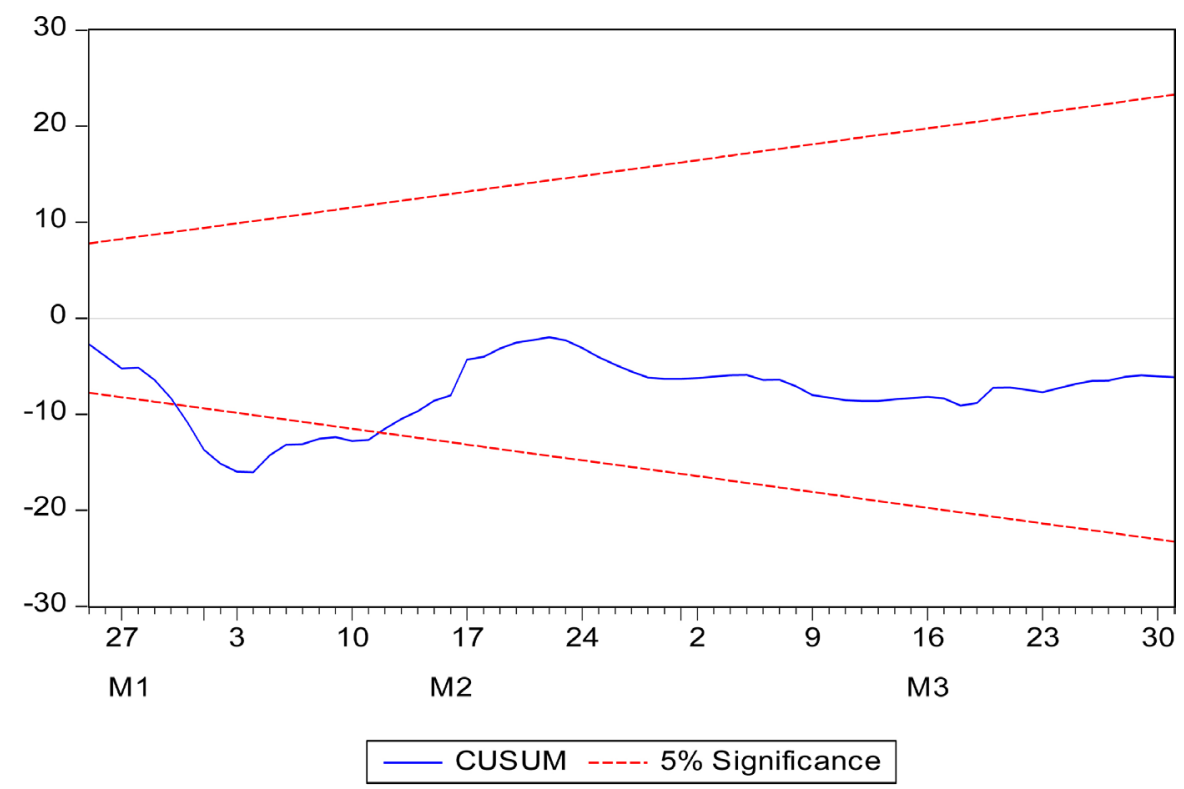

Figure 4. Stability test for the impacts of COVID-19 pandemic on crude oil price and food price index.

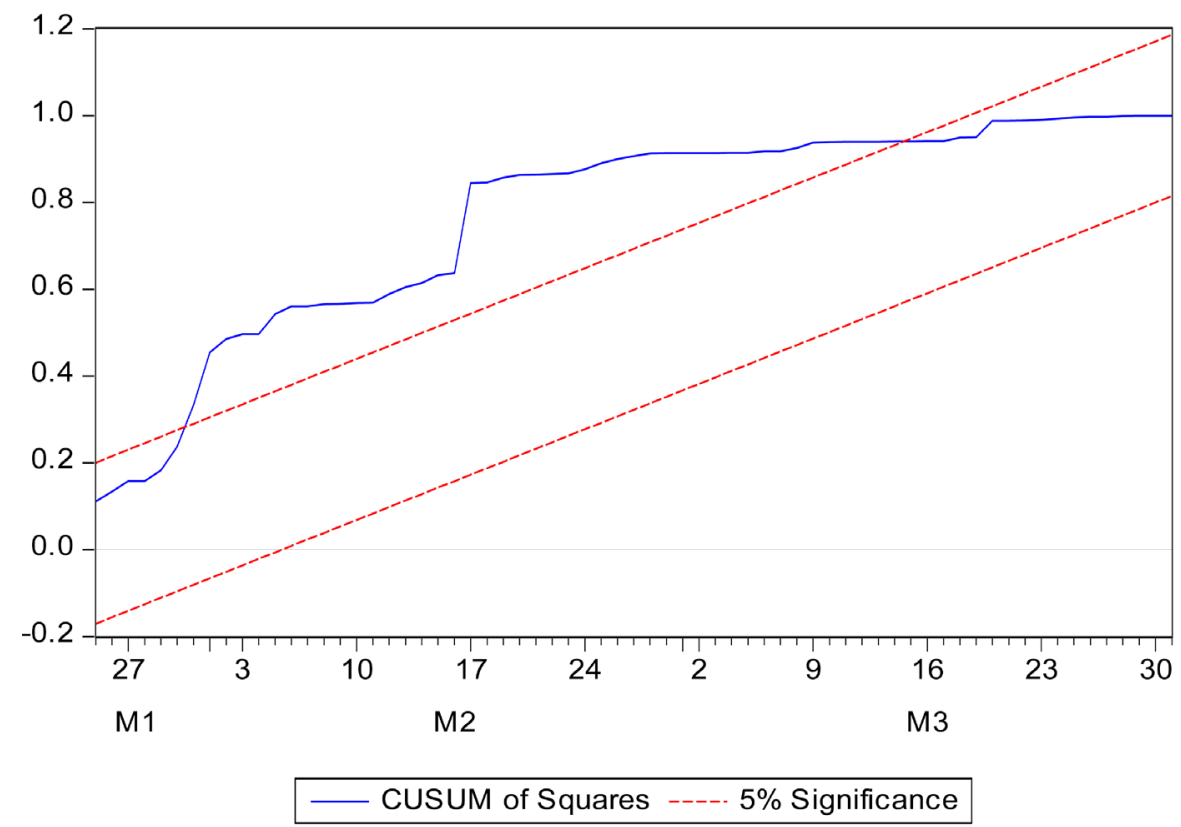

Figure 5. Stability test for the impacts of COVID-19 pandemic on crude oil price and food price index. 
Table 9. Estimated results for the impacts of COVID-19 pandemic on crude oil price and food price index using time series Dynamic OLS, Fully modified OLS and Canonical CR.

\begin{tabular}{|c|c|c|c|c|c|c|}
\hline \multirow{2}{*}{$\begin{array}{c}\text { Dependent Variable }=C V C: \\
\text { Regressors }\end{array}$} & \multicolumn{2}{|c|}{ DOLS } & \multicolumn{2}{|c|}{ FMOLS } & \multicolumn{2}{|c|}{ CCR } \\
\hline & Coefficients & SE & Coefficients & SE & Coefficients & $\mathrm{SE}$ \\
\hline Oil price & $-2.193^{\mathrm{a}}(-3.550)$ & 0.617 & $-1.168^{\mathrm{c}}(-1.755)$ & 0.665 & $-1.200^{c}(-1.771)$ & 0.677 \\
\hline Food prices & $-63.261^{\mathrm{a}}(-7.323)$ & 8.638 & $-70.252^{\mathrm{a}}(-6.405)$ & 10.968 & $-69.274^{\mathrm{a}}(-6.395)$ & 10.831 \\
\hline Constant & $344.810^{\mathrm{a}}(8.012)$ & 43.033 & $377.838^{\mathrm{a}}(6.894)$ & 54.803 & $372.919(6.899)$ & 54.049 \\
\hline $\mathrm{R}^{2}$ & \multicolumn{2}{|c|}{0.918} & \multicolumn{2}{|c|}{0.787} & \multicolumn{2}{|c|}{0.788} \\
\hline Adjusted $\mathrm{R}^{2}$ & \multicolumn{2}{|l|}{0.907} & \multicolumn{2}{|l|}{0.781} & \multicolumn{2}{|c|}{0.782} \\
\hline Normality Test: & \multicolumn{2}{|c|}{$47.025^{\mathrm{a}}[0.000]$} & \multicolumn{2}{|c|}{$2.904[0.234]$} & \multicolumn{2}{|c|}{$3.519[0.172]$} \\
\hline
\end{tabular}

Sources: Authors computation using EViews 9; Note. Numbers in brackets are the t-statistics and Numbers in [ ] are the Jarque-Bera P-Values. DV = Dependent variable, DOLS = dynamic ordinary least squares; FMOLS = fully modify ordinary least square; OLS = Ordinary Least Square; SE = standard error. a\&cindicates significant at 1 and $10 \%$ levels of significance respectively.

Table 10. Vector error correction model granger causality test result.

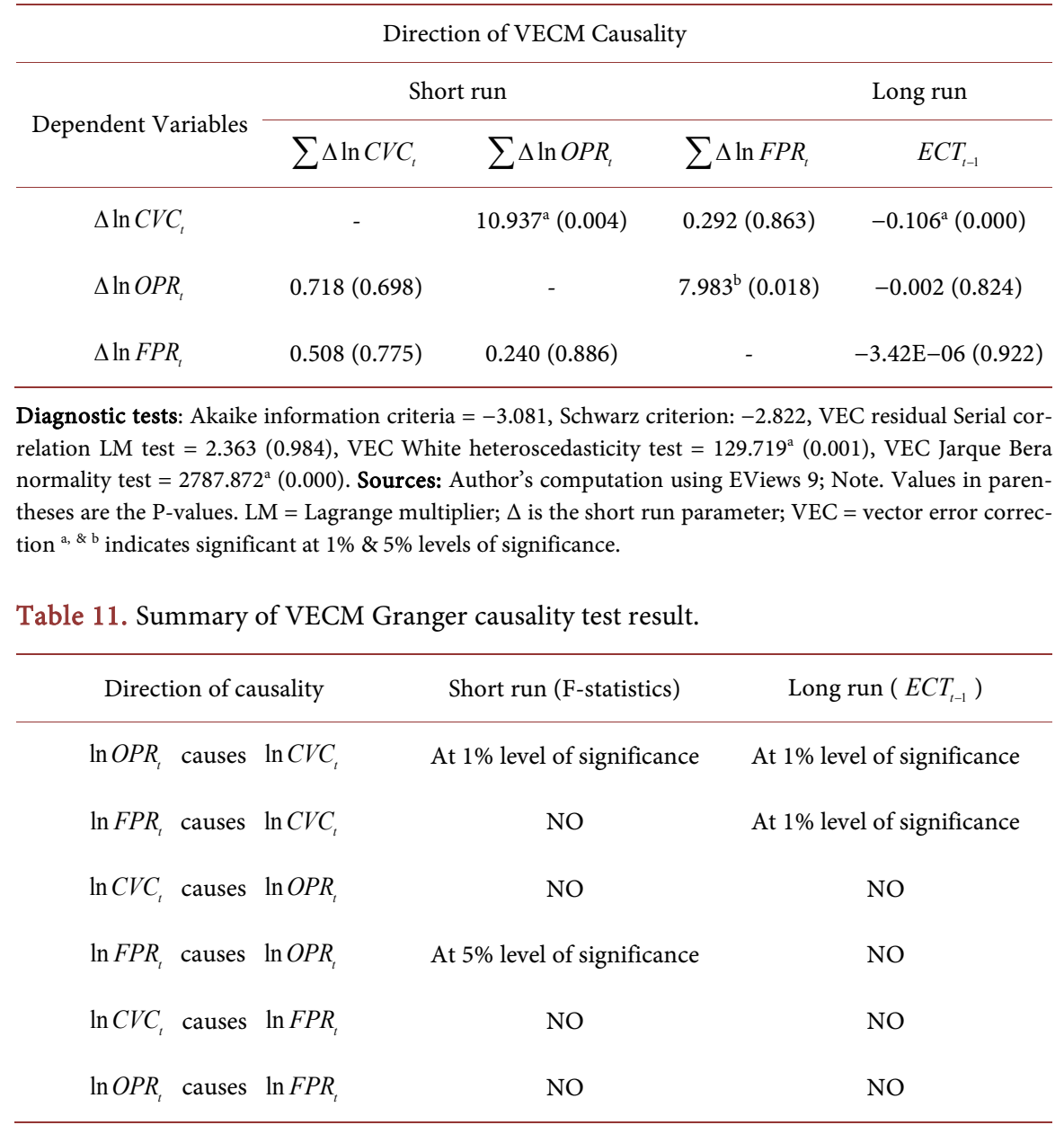

Source: Author's computation using EViews 9.

Apart from the long run causality, the short run causality was also reported in Table 10. However, in the short run, there is unidirectional causality from run- 
ning from crude oil price to infected cases of COVID-19 pandemic and from food price index to crude oil prices. The rest of the interpretations with regards to the long run and short run causality results are offered in Table 11.

The VECM reliability tests results are reported in the lower part of Table 10 which indicates that the model is steady and reliable as all the null hypothesis of serial correlation LM test could not be rejected, and therefore its coefficients are acceptable for statistical reasoning.

The summary of the vector error correction model granger causality test result in terms of both short run causality and long run causality is presented in Table 11.

\section{Summary, Conclusion and Recommendations}

The study determines the impact of COVID-19 pandemic on crude oil price and food price index. ARDL bound test was utilized to determine the cointegration relationship among the crude oil price, food price index and COVID-19 pandemic. ARDL model together with ARDL error correction model was employed to determine the long run coefficients, short run coefficients and the error correction term respectively. The bound test result indicates the existence of cointegration relationship among the three variables. The long run ARDL model revealed that crude oil price with the exception of food price index was negative and significant due changes in the infected cases of COVID-19 pandemic and the result from the short run ARDL model revealed that crude oil prices and food price index were negative and significantly associated with the changes in infected cases of COVID-19 pandemic. As far as the corresponding short run error correction term is concerned, the coefficient of speed of adjustment satisfied all the econometrics requirements, and $4.2 \%$ of the previous day's deviation from the equilibrium is corrected in the current days. All the reliability tests for the model revealed that the model is reliable and statistically fit.

The checking for robustness was done using DOLS, FMOLS and CCR and their results corroborate the outcomes of long run ARDL model. The VECM Granger causality was applied to test the direction of causality which revealed significant long run causality in infected cases of COVID-19 pandemic equation and there is short run unidirectional causality running from crude oil prices to infected cases of COVID-19 pandemic and from food price index to crude oil prices.

Following the outbreak of coronavirus, countries around the world started to implement a number of policy measures aimed at avoiding the further spread of the disease. Measures affecting the free movement of people, such as seasonal workers, might have an impact on food production, thus affecting market prices globally. FAO recommends the following measures:

1) Countries should meet the immediate food needs of their vulnerable populations.

Ensure emergency food needs are met; adjust and expand social protection 
programmes; scale up nutritional support; support management and prevention of undernourishment; adjust school meal programs so as to continue delivering school meals even when schools are shut [20].

2) Countries should boost their social protection programmes.

This could entail: increasing transfer amounts to people already benefiting from social assistance through a one-off payment (prior to full blown impact of the crisis as an early action to mitigate impact) or ensure multiple payments to help families meet their basic needs; providing complementary entitlements to offset loss of income by small scale producers, for example; if food insecurity becomes extremely severe due to massive layoffs, fall in remittances [20].

3) Countries should gain efficiencies and try to reduce trade related costs.

These include: not impose measures that would restrict trade and mobility of commodities; reduce food waste and looses; resolve logistics bottlenecks; immediately review trade and policy options and their likely impacts; avoid generalized subsidies for food consumers; reduce restrictions on use of stocks; reduce import tariffs when governments think is appropriate to minimize, for example, when there is an increase in costs because of devaluation of their currencies and other restrictions; temporarily reduce VAT and other taxes; if needed, review taxation policy to imported goods to compensate from potential cost increases (because of exchange devaluation) and assess exchange devaluation's potential impacts [20].

\section{Funding}

The author(s) received no financial support for the research, authorship, and/or publication of this article.

\section{Conflicts of Interest}

The authors declare no conflicts of interest regarding the publication of this paper.

\section{References}

[1] World Health Organization (2020) Novel Coronavirus (2019-nCoV) Situation Reports Parts 1, 20th January 2020. 1-5.

https://www.who.int/emergencies/diseases/nevel-coronavirus-2019/situation-reports

[2] World Health Organization (2020) Novel Coronavirus (2019-nCoV) Situation Reports Part 11, 31st January 2020. 1-5. https://www.who.int/emergencies/diseases/nevel-coronavirus-2019/situation-reports

[3] World Health Organization (2020) Novel Coronavirus (2019-nCoV) Situation Reports Parts 12, 1st February 2020. 1-7. https://www.who.int/emergencies/diseases/nevel-coronavirus-2019/situation-reports

[4] World Health Organization (2020) Coronavirus Disease 2019 (2019-nCoV) Situation Reports Parts 40, 29th February 2020. 1-7. https://www.who.int/emergencies/diseases/nevel-coronavirus-2019/situation-reports

[5] World Health Organization (2020) Coronavirus Disease 2019 (2019-nCoV) Situa- 
tion Reports Parts 41, 1st March 2020. 1-7.

https://www.who.int/emergencies/diseases/nevel-coronavirus-2019/situation-reports

[6] World Health Organization (2020) Coronavirus Disease 2019 (2019-nCoV) Situation Report 71, 31st March 2020. 1-11.

https://www.who.int/emergencies/diseases/nevel-coronavirus-2019/situation-reports

[7] World Health Organization (2020) Coronavirus Disease 2019 (2019-nCoV) Situation Report 72, 1st April 2020. 1-12.

https://www.who.int/emergencies/diseases/nevel-coronavirus-2019/situation-reports

[8] World Health Organization (2020) Coronavirus Disease 2019 (2019-nCoV) Situation Report 101, 30th April 2020. 1-13.

https://www.who.int/emergencies/diseases/nevel-coronavirus-2019/situation-reports

[9] Global Oil Demand to Decline in 2020 as Coronavirus Weighs Heavily on Markets. https://www.iea.org/news/global-oil-demand-to-decline-in-2020-as-coronavirus-we ighs-heavily-on-markets

[10] Food and Agricultural Organization (2020) Whose Food Security and Livelihoods Are Most at Risk Due to the Pandemic? http://www.fao.org/2019-ncov/en

[11] Food and Agricultural Organization (2020) Will COVID-19 Have Negative Impacts on Global Food Security? http://www.fao.org/2019-ncov/en

[12] Food and Agricultural Organization (2020) How Will the Pandemic Affect Food Demand? http://www.fao.org/2019-ncov/en

[13] Maijama'a, R., Musa, K.S., Garba, A. and Baba, U.M. (2020) Coronavirus Outbreak and the Global Energy Demand: A Case of People's Republic of China. American Journal of Environmental and Resource Economics, 5, 10-13.

[14] World Health Organization (2020) Coronavirus Disease 2019 (2019-nCoV) Situation Reports 1-101, Data on the Infected Cases of COVID-19.

https://www.who.int/emergencies/diseases/nevel-coronavirus-2019/situation-reports

[15] Data on Crude Oil Price Is Sourced from Macro Trend Website. https://www.macrotrends.net/2516/wti-crude-oil-prices-10-years-daily-chart

[16] Food and Agricultural Organization (2020) FAO Food Price Index. http://www.fao.org/worldfoodsituation/foodpricesindex/en

[17] Musa, K.S., Maijama'a, R., Muhammed, N. and Usman, A. (2020) Crude Oil Price and Exchange Rate Nexus: An Ardl Bound Approach. Open Access Library Journal, 7, e6072. https://doi.org/10.4236/oalib.1106072

[18] Sims, C.A., Stephen, M.G. and Jeffrey, D.S. (1982) Policy Analysis with Econometrics Models. Brooking Papers on Economic Activity, 13, 107-164. https://www.jstor.org/stable/2534318 https://doi.org/10.2307/2534318

[19] Pesaran, M.H. and Pesaran, B. (1997) Microfit 4.0. Oxford University Press, Oxford.

[20] Food and Agricultural Organization (2020) What Are FAO's Recommendations to Mitigate the Risks of the Pandemic on Food Security and Nutrition? http://www.fao.org/2019-ncov/en 